\title{
HMGN1 Gene
}

National Cancer Institute

\section{Source}

National Cancer Institute. HMGN1 Gene. NCI Thesaurus. Code C20581.

This gene is involved in chromatin remodeling and enhancing gene transcription from chromatin templates. 